\begin{tabular}{cc|c}
\hline Tar. Bil. Der. & Journal of Agricultural Sciences \\
& $\begin{array}{c}\text { Dergi web sayfası: } \\
\text { www.agri.ankara.edu.tr/dergi }\end{array}$ & Journal homepage: \\
& www.agri.ankara.edu.tr/journal
\end{tabular}

\title{
Bazı Lahanagil (Cruciferae) ve Baklagil (Fabaceae) Türlerinin Tohum Filizlerindeki Kimyasal Özelliklerin Değişimi ve Beslenme Değeri
}

\author{
Levent ARIN ${ }^{\mathrm{a}}$, Muhammet ARICI ${ }^{\mathrm{b}}$, Serdar POLAT ${ }^{\mathrm{a}}$, Ertan ATEŞ ${ }^{\mathrm{c}}$ \\ ${ }^{a}$ Namık Kemal Üniversitesi, Ziraat Fakültesi, Bahçe Bitkileri Bölümü, 59030, Tekirdă̆, TÜRKIYE \\ ${ }^{b}$ Ylldız Teknik Üniversitesi, Kimya-Metalurji Fakültesi, Gıda Mühendisliği Bölümü, 34220, Esenler-İstanbul, TÜRKIYE \\ ${ }^{c}$ Namık Kemal Üniversitesi, Ziraat Fakültesi, Tarla Bitkileri Bölümü, 59030, Tekirdağ, TÜRKIYYE
}

\section{ESER BİLGISİ}

Araştırma Makalesi

DOI: 10.1501/Tarimbil_0000001282

Sorumlu Yazar: Levent ARIN, E-posta: larin@nku.edu.tr, Tel: +90 (282) 2502054

Geliş Tarihi: 26 Eylül 2013, Düzeltmelerin Gelişi: 27 Aralık 2013, Kabul: 07 Şubat 2014

\section{ÖZET}

Cruciferae ve Fabaceae familyasına ait bazı türlerin tohumları (Brokoli, Brüksel lahanası, Soya ve İran üçgülü) filiz tüketimi amacıyla 1şık, 12 saat 1 şı + 12 saat karanlık ve tamamen karanlık koşullarda ayrı ayrı ya da karışımlar halinde bitki büyüme kabininde $20 \pm 1{ }^{\circ} \mathrm{C}$ 'de 5 gün süreyle çimlendirilmiştir. Iş̧k koşullarında çimlendirilen tüm filizlerin protein, şeker ve $\mathrm{C}$ vitamini içeriği, karanlıkta yetiştirilenlere göre daha yüksek bulunmuştur. Protein içeriği $2.21 \mathrm{~g} 100$

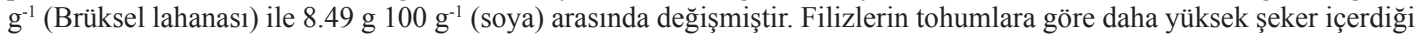
ve filizlerin C vitamini kapsamının tohumlarla karşılaştırıldığında yaklaşık 3 ile 9 kat daha fazla olduğu tespit edilmiştir. Kalsiyum, fosfor ve potasyum seviyeleri bakımından tohumlar ve filizler arasında farklılık görülmemiştir.

Anahtar Kelimeler: Brokoli; Brüksel lahanası; Soya; İran üçgülü; Tohum filizi; Çimlendirme koşulları

\section{Changes in Chemical Properties of Seed Sprouts of Some Cruciferae and Fabaceae Species and Their Nutritional Value}

\author{
ARTICAL INFO \\ Research Article \\ Corresponding Author: Levent ARIN, E-mail: larin@nku.edu.tr, Tel: +90 (282) 2502054 \\ Received: 26 September 2013, Received in Revised Form: 27 December 2013, Accepted: 7 February 2014
}

\begin{abstract}
The seeds of some species in Cruciferae and Fabaceae (Broccoli, Brussels sprout, soybean, Persian clover) were germinated for sprout consumption either alone or as mixtures under the full day light, 12 hours light +12 hours darkness and fully darkness conditions in growth chamber at $20 \pm 1{ }^{\circ} \mathrm{C}$ for 5 days. Protein, sugar and vitamin $\mathrm{C}$ contents in all sprouts germinated under light conditions were higher than that of grown under dark conditions. Protein content was

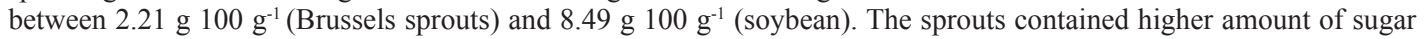
than seeds. Vitamin $\mathrm{C}$ content of sprouts were approximately three to nine fold higher than their seeds. No significant differences were found between sprouts and their seeds for calcium, phosphorus and potassium contents.
\end{abstract}

Keywords: Broccoli; Brussels sprout; Soybean; Persian clover; Seed sprout; Germination conditions 


\section{Giriș}

Gıda olarak tohum filizi kullanımı, Uzak Doğu orijinlidir ve son yıllarda minimum seviyede işlenmiş, katkısız, doğal, besleyici ve sağlıklı g1dalara yönelim nedeniyle batı dünyasında da yaygınlaşmıştır (Plaza et al 2003; Weiss \& Hammes 2005). Örneğin, Amerikalıların \% 10’u düzenli olarak tohum filizi tüketmektedir. ABD'de üretilen tohum filizi yaklaşı 300.000 tona ve 250 milyon dolarlık bir pazar değerine ulaşmaktadır (Kurtzweil 1999). Kore'de ise temel gidalar arasinda yer alan soya filizinin yıllık üretimi yaklaşı 480.000 ton ve pazar payı 360-480 milyon dolar arasındadır (No et al 2003; Kim et al 2006). Genel olarak, su kapsamı düşük ve besin içeriği yüksek olan tohumların çimlendirilmesi ile protein, vitamin ve diğer besin elementlerinin biyolojik yarayışlılığ yükselmekte, toksin ve enzim inhibitörlerinin etkinliği azalıp sindirilebilirliği artmaktadır. Tohumlar, serbest radikallerin olumsuz etkilerini azaltan antioksidanlar bakımından zengindir. Ayrıca, zararlı kolesterolü azaltıcı ve diyabetiklerin yaşam kalitesinin iyileştirici, ileri yaşlarda bir göz kusuru olan makular dejenerasyonu geciktirici ve başta kanser olmak üzere birçok hastalığı önleyici etkilere sahip oldukları belirtilmektedir (Zielinski et al 2005; PHY 2014).

Tohum filizi üretiminde genellikle buğdaygil (Gramineae) ve baklagil (Fabaceae) tohumları kullanılmaktadır. Baklagiller içerisinde en çok üretilen ve bilineni, fenolik bileşiklerce zengin olan soya filizidir (Kim et al 2006). Soya, yüksek kalitede protein ve amino asit içeriği nedeniyle de birçok araştırmaya konu olmuştur. Doğu ülkelerinde akciğer, kolon, prostat kanseri, oesteoporosis ve kalp-damar hastalıklarının ender görülmesinin yoğun soya ve soya ürünleri tüketimi ile ilişkili olabileceği bildirilmektedir (Plaza et al 2003). Son yıllarda fonksiyonel gıda arayışına paralel olarak hastalıkların önlenmesi ve tedavisindeki olumlu etkileri nedeniyle lahanagil (Cruciferae) familyası türlerine de artan bir ilgi görülmektedir. Bu türlerin tüketilmesiyle, DNA zararlanmasının azalabileceği, deoksidatif enzim seviyesinin artabileceği ve içerdikleri methylsulphinylalkyl glucosionalat'tan oluşan isothiocyanatın kanser riskinin azaltılmasında önemli olabileceği öne sürülmektedir (Faulkner et al 1998). Ayrıca, üç günlük brokoli filizinin normal sebzeye göre çok fazla sulforaphane içerdiği ve az miktarda filiz tüketiminin çok fazla sebze tüketilmesine karşılık gelecek şekilde kansere karş1 etkili olabileceği (Fahey et al 1997), çimlenen brokoli tohumunun antikanser enzim üretimini stimüle ettiği (Fahey 2005), filizlerin sulforaphana dönüşebilen glucoraphanini yüksek düzeyde içerdiği (Farnham 2005) ifade edilmektedir. Tek türden elde edilen filizlerin besin değeri, biyoaktif bileşenler ve mineral madde kapsamına, tohumların 1slatılma ve çimlendirme süresine, ortam sıcaklığı ve nemine, kullanılan tohum ve çeşide, muhafaza ve depolama koşullarına göre farklılık gösterebilmektedir (Krug 1991; Plaza et al 2003; Kim et al 2006; Billings 2014).

Ülkemizde tohum filizine ancak büyük tüketim merkezlerindeki bazı marketlerde ve sınırlı sayıda türde rastlanılmaktadır. Toplumumuz için oldukça yeni sayılabilecek tohum filizi konusunda yapılan bilimsel araştırmalar ve veri kaynakları yok denecek kadar azdır (Arın 1997; Orhun \& Arın 2008). Bu çalışma, lahanagil ve baklagil familyalarına ait bazı türlerin (brokoli, Brüksel lahanası, soya ve İran üçgülü) tohumlarının ayrı ayrı ve karışımlar halinde farklı 1şık koşulları altında çimlendirilmesinin tohum filizinin protein, şeker, C vitamini, kalsiyum, fosfor ve potasyum içeriği üzerine etkilerinin belirlenmesi amacıyla yürütülmüştür. Ayrıca ülkemizde konuyla ilgili ileride yürütülecek çalışmalar için ön bilgilere ulaşılması hedeflenmiştir.

\section{Materyal ve Yöntem}

\subsection{Bitkisel materyal}

Çalışma, Namık Kemal Üniversitesi, Ziraat Fakültesi, Bahçe Bitkileri Bölümü’nde yürütülmüşsür. Bitkisel materyal olarak tohum filizinin üretiminde yaygın olarak kullanılan türler seçilmiştir; brokolinin (Brassica oleracea L. var. italica) Jade $\mathrm{F}_{1}$ çeşidi, Brüksel lahanasının (Brassica oleracea $\mathrm{L}$. var. gemmifera) Nautic $\mathrm{F}_{1}$ çeşidi, aynı Fakültenin Tarla Bitkileri Bölümü tarafından saf hat 
seleksiyonu ile geliştirilen soyanın (Glycine max. L.) YM hatt1 ve İran üçgülünün (Trifolium resupinatum L. var. majus Boiss.) S üçgül hattı kullanılmıştır. Brokoli, soya ve İran üçgülünde o yılın herhangi bir koruyucu kimyasal ya da pestisit ile muamele edilmemiş tohumları kullanılmıştır. Bu nitelikte tohum bulmanın güç olduğu Brüksel lahanasında ise organik tohumlar kullanılmıştır. Tohumlar tek veya karışım halinde çimlendirilmiştir. Tohum ve tohum karışım oranları ve uygulama kodları çizelge 1'de verilmiştir. Ağırlık bazında her bir tohum ve tohum karışımından $8 \mathrm{~g}$ kullanılmıştır.

\subsection{Tohumların hazırlanması ve çimlendirme}

Deneme başlangıcında tohum örneklerinin çimlenme oranları, protein, toplam şeker, C vitamini, kalsiyum $(\mathrm{Ca})$, fosfor $(\mathrm{P})$ ve potasyum (K) içerikleri belirlenmiştir (Çizelge 2). Uygulama öncesinde tohumlar önce suda yıkanarak yabancı materyallerden arındırılmış, 20.000 ppm'lik $\mathrm{Ca}(\mathrm{OCl})_{2}$ çözeltisinde 5 dakika tutularak yüzey sterilizasyonu yapılmış (Söylemez et al 2001; Weiss \& Hammes 2005), yıkanmış ve 5 saat süreyle ıslatmaya bırakılmıştır. Tohumlar, $17 \mathrm{x}$ 12 x $6 \mathrm{~cm}$ boyutlarındaki hijyenik gıda kapları ve kaplara uygun sökülebilir nitelikte tel 1zgaralar üzerine serilerek bitki büyüme kabinine alınmıştır. Çimlendirmeye alınan tohumlara üç farklı 1şıklanma süresi uygulanmıştır; (1) 24 saat aydınlık (1şık), (2) 12 saat aydınlık + 12 saat karanlık (1şık+karanlık) ve (3) tamamen karanlık. Bitki büyüme kabininde 1şık yoğunluğu 17.000 lüks, ortam sicaklığ $20 \pm 1$ ${ }^{\circ} \mathrm{C}$ ve oransal nem $\% 60 \pm 5$ koşulları sağlanmıştır. Tohumlar beş gün süreyle çimlendirilmiştir. Bu süre içinde tohumların suları günde iki kez drene edilmiş, tohumlar akan su altında yıkanmış ve yeniden bitki büyüme kabinine alınmıştır.

\section{Çizelge 1- Uygulama kodları, tohumları çimlendirilen türler ve karışım oranları}

Table 1- Name of species, mixing ratios and treatment codes

\begin{tabular}{llc}
\hline $\begin{array}{l}\text { Uygulama } \\
\text { numarası }\end{array}$ & Tür / Karışım & $\begin{array}{c}\text { Karışım } \\
\text { oranı }\end{array}$ \\
\hline I & Brokoli & \\
II & Brüksel lahanası & \\
III & Soya & \\
IV & İran üçgülü & $1: 1$ \\
V & Brokoli+Brüksel lahanası & $1: 1$ \\
VI & Soya+İran üçgülü & $1: 1$ \\
VII & (Brokoli+Brüksel lahanasi) + (Soya+İran üçgülü) & $3: 1$ \\
VIII & (Brokoli+Brüksel lahanas1) + (Soya+İran üçgülü) & $1: 3$ \\
IX & (Brokoli+Brüksel lahanas1) + (Soya+İran üçgülü) & \\
\hline
\end{tabular}

Çizelge 2- Brokoli, Brüksel lahanası, soya ve İran üçgülü tohumlarının protein, toplam şeker, C vitamini, kalsiyum, fosfor, potasyum içerikleri ve çimlenme oranı

Table 2- Germination percentages and protein, total sugar, vitamin C, calcium, phosphorus and potassium contents of broccoli, Brussels sprouts, Persian clover and Soybean seeds

\begin{tabular}{|c|c|c|c|c|c|c|c|}
\hline Ürün & $\begin{array}{l}\text { Çimlenme } \\
\text { oranı }(\%)\end{array}$ & $\begin{array}{c}\text { Protein } \\
\left(\mathrm{g} 100 \mathrm{~g}^{-1}\right)\end{array}$ & $\begin{array}{c}\text { Şeker } \\
\left(\mathrm{g} 100 \mathrm{~g}^{-1}\right)\end{array}$ & $\begin{array}{c}\text { C vitamini } \\
\left(\mathrm{mg} 100 \mathrm{~g}^{-1}\right)\end{array}$ & $\begin{array}{c}\text { Kalsiyum } \\
\left(\mathrm{mg} 100 \mathrm{~g}^{-1}\right)\end{array}$ & 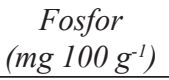 & 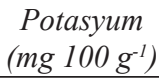 \\
\hline Brokoli & 75 & 2.51 & 1.67 & 27.10 & 35.7 & 65.5 & 322.7 \\
\hline B. lahanas1 & 92 & 2.49 & 3.01 & 25.10 & 47.1 & 55.5 & 312.7 \\
\hline Soya & 90 & 9.51 & 1.71 & 3.70 & 162.8 & 64.7 & 439.8 \\
\hline İran üçgülü & 73 & 6.17 & 0.98 & 1.20 & 112.7 & 47.0 & 86.8 \\
\hline
\end{tabular}




\subsection{Kimyasal analizler}

Çimlendirme sonrasında, tohum filizleri havlu kağıt üzerinde yaklaşık iki saat süreyle bekletilmiş ve fazla suyun uzaklaşması sağlanmıştır. Cam petri kapları içine alınan filizler $55^{\circ} \mathrm{C}$ 'lik etüvde ağırlıkları sabit kalıncaya kadar kurutulmuş, öğütülerek ağızları kilitli hava geçirmez plastik poşetlere alınmış ve analiz yapılıncaya kadar buzdolabinda $5 \pm 1{ }^{\circ} \mathrm{C}$ 'de muhafaza edilmiştir. Tohum filizi örneklerinde mikro Kjeldahl yöntemiyle protein $\left(\mathrm{g} 100 \mathrm{~g}^{-1}\right)$, TOKB (1988)'e göre toplam şeker (g $\left.100 \mathrm{~g}^{-1}\right)$, Pearson (1970)'a göre C vitamini (mg $100 \mathrm{~g}^{-1}$ ) ve spektrofotometrik olarak kalsiyum, fosfor ve potasyum miktarları (mg $100 \mathrm{~g}^{-1}$ ) belirlenmiştir (AOAC 1999). Deneme, faktöriyel düzende tesadüf parselleri deneme deseninde üç tekerrürlü olarak yürütülmüş, veriler TARISST (Açıkgöz et al 1994) paket programı ile variyans analizine (ANOVA) tabii tutulmuş ve LSD testi gerçekleştirilmiştir.

\section{Bulgular ve Tartışma}

\subsection{Protein}

Tohum filizlerindeki protein içeriği açısından uygulamaların ana etkileri ile interaksiyon önemli bulunmuştur ve 1şılanma süresinin değişimi ile farklı türlerin tohum filizlerinin protein içeriği değişim göstermiştir $(\mathrm{P}<0.01)$. Işık süresinin azalmasına paralel olarak protein içeriğinin azaldı $\breve{g}_{1}$ belirlenmiştir. En yüksek protein miktarı 1 şı koşullarında yetiştirilen filizlerde (5.02 g $\left.100 \mathrm{~g}^{-1}\right)$, en düşük değer ise tamamen karanlıkta yetiştirilen

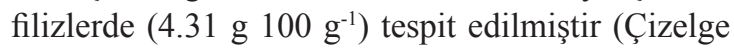
3). Öte yandan, çimlendirme öncesi tohumların sahip oldukları protein içeriklerine paralel olarak (Çizelge 2), en yüksek protein kapsamı soya

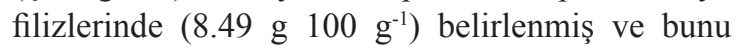
üçgül-soya karışımı (1:1) izlemiştir. İnteraksiyon açısından değerlendirildiğinde, en yüksek protein kapsamı bütün 1şıklanma koşullarında (1şık, 1şık+karanlık, karanlık) en yüksek değer veren soya filizlerinden elde edilmiştir (sırasıyla $8.99,8.46$ ve

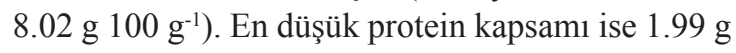
$100 \mathrm{~g}^{-1}$ ile karanlıkta çimlendirilen Brüksel lahanası filizlerinde tespit edilmiştir.

Genel olarak, bütün türlerin tohum ve karışımlarda 1şıktan karanlığa doğru gidildikçe düzenli azalış görülmüştür. Bu sonuç, filizlerdeki protein metabolizmasının 1şık koşullarda daha hızlı çalışması ile ilişkilidir. Ayrıca tohumların başlangıçta sahip oldukları protein içeriklerini çimlendirme sonrası da yaklaşık olarak korudukları gözlenmiştir. Örneğin, soyada çimlendirme öncesi ve sonrasında

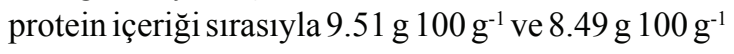
olmuştur. Baklagil türlerinin lahanagil türlerine göre daha yüksek protein içerdiğiyle ilgili bilinen genel durum tohumların çimlendirilmesi sonrası da ortaya çıkmış ve tohum karışımlarında da görülmüştür. Bu çalışmada, 1şı koşulları ve türlere göre değişmekle

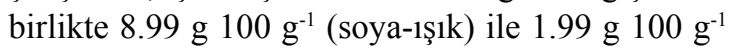
(Brüksel lahanası-karanlık) arasında protein miktarı tespit edilmiştir. Sonuçlar, turpta $1.4 \mathrm{~g}$ ve soyada

Çizelge 3- Tohum karışımları ve ışıklanmanın filizlerin protein içeriği üzerine etkileri (g $\left.100 \mathrm{~g}^{-1}\right)$

Table 3-Effect of light and seed mixture on protein content $\left(g 100 \mathrm{~g}^{-1}\right)$ of sprouts

\begin{tabular}{lcccccccccc}
\hline \multirow{2}{*}{ Işık koşulları } & \multicolumn{10}{c}{ Protein miktarı $\left(\mathrm{g} 100 \mathrm{~g}^{-1}\right)$} \\
\cline { 2 - 11 } & $I$ & $I I$ & $I I I$ & $I V$ & $V$ & $V I$ & $V I I$ & $V I I I$ & $I X$ & Ortalama \\
\hline Işık & $2.56 \mathrm{q}$ & $2.39 \mathrm{~s}$ & $8.99 \mathrm{a}$ & 5.701 & $2.53 \mathrm{qr}$ & $7.58 \mathrm{p}$ & $5.40 \mathrm{j}$ & $3.78 \mathrm{n}$ & $6.28 \mathrm{~g}$ & $5.02 \mathrm{a}$ \\
Işık+Karanlık & $2.39 \mathrm{~s}$ & $2.25 \mathrm{t}$ & $8.46 \mathrm{~b}$ & $5.19 \mathrm{k}$ & $2.44 \mathrm{rs}$ & $6.80 \mathrm{e}$ & 5.061 & $3.48 \mathrm{o}$ & $5.86 \mathrm{~h}$ & $4.66 \mathrm{~b}$ \\
Karanlık & $2.21 \mathrm{t}$ & $1.99 \mathrm{u}$ & $8.02 \mathrm{c}$ & $4.80 \mathrm{~m}$ & $2.07 \mathrm{u}$ & $6.41 \mathrm{f}$ & $4.69 \mathrm{~m}$ & $3.23 \mathrm{p}$ & $5.39 \mathrm{j}$ & $4.31 \mathrm{c}$ \\
\hline Ortalama & $2.38 \mathrm{~g}$ & $2.21 \mathrm{~h}$ & $8.49 \mathrm{a}$ & $5.23 \mathrm{~d}$ & $2.35 \mathrm{~g}$ & $6.93 \mathrm{~b}$ & $5.05 \mathrm{e}$ & $3.50 \mathrm{f}$ & $5.84 \mathrm{c}$ &
\end{tabular}

Tohum filizi karışımları, $\mathrm{LSD}_{0.01}=0.087$; 1şı koşulları, $\mathrm{LSD}_{0.01}=0.050$; interaksiyon, $\mathrm{LSD}_{0.01}=0.115$ 
9.0 g protein olduğunu bildiren No et al (2003) ile turp, kolza ve hardal gibi lahanagil türlerinin tohumlarında 2.16-2.86 g ve filizlerinde 2.08-3.27 $\mathrm{g}$ arasında protein bulunduğunu, ayrica tohuma göre filizlerde bazen az, bazen çok ama genel olarak birbirine yakın değerde protein olduğunu ifade eden Zielinski et al (2005)'in bulgularıla benzerlik göstermektedir. Farklı 1şıklanma sürelerine bağlı olarak soya filizlerinde belirlediğimiz protein miktarı (8.02-8.99 g $\left.100 \mathrm{~g}^{-1}\right)$, soya filizinde 0.7$2.0 \mathrm{~g}$ protein bulunduğunu belirten Krug (1991)'a ve aynı türde protein miktarının $5.8 \mathrm{~g}$ olduğunu bildiren Liebster (1991)'a göre daha yüksektir. Bu farklılı̆̆ın çeşit, tohumun iriliği, ağırlığı ve kimyasal kompozisyonu, 1slatma süresi, sicaklık vb. (No et al 2003; Plaza et al 2003) faktörlerden kaynaklanmış olabileceği düşünülmektedir.

\subsection{Toplam şeker}

Toplam şeker içeriği bakımından uygulamaların ana etkileri ve interaksiyon önemli çıkmıştır $(\mathrm{P}<0.01)$. Protein içeriğine benzer şekilde, en yüksek şeker miktarı 1şık koşullarında (2.43 g 100 $\left.\mathrm{g}^{-1}\right)$ tespit edilmiş ve 1 şı azaldıkça şeker miktarı da azalmıştır (Çizelge 4). Türler açısından, çimlendirme öncesi en yüksek şeker (3.01 g $\left.100 \mathrm{~g}^{-1}\right)$ içeriğine sahip Brüksel lahanası tohumları (Çizelge 2)

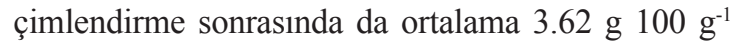
ile en büyük değeri vermiştir. Işık ve türler birlikte değerlendirildiğinde, en yüksek şeker içeriği (3.88 g $100 \mathrm{~g}^{-1}$ ) 1şı k koşullarında çimlendirilen Brüksel lahanasında bulunmuş ve bunu sırasıyla yine karanlık ve 1 şık+karanlık koşullarında çimlenen filizleri izlemiştir. En düşük şeker seviyesi ise İran üçgülünün 1şık + karanlık ve karanlık uygulamalarından elde edilmiştir. Işık koşullarda çimlendirilen tohumların, yarı 1şık ve karanlık koşullarda çimlendirilenlere göre daha yüksek şeker içeriğine sahip olmasının filizlerin fotosentez yapması, böylece karbonhidrat birikiminin ve sekonder metabolit oluşumunun hızlı gerçekleşmesi ile ilişkili olduğu belirtilmektedir (Kim et al 2006). Bütün türlerin filizlerinde, tohumların başlangıç şeker içeriklerine göre az da olsa artış belirlenmiştir. Öte yandan tohumların şeker içeriklerindeki sıralama, filizlerine de yansımıştır. Örneğin tohumunda $3.01 \mathrm{~g}$ ile en yüksek şekere sahip Brüksel lahanası, çimlendirme sonrası $3.62 \mathrm{~g}$ ile en büyük değeri vermiştir. Zielinski et al (2005)'da lahanagillerden findık turpu, iri turp, kolza ve hardalda karbonhidratlar bakımından çimlendirme ile tohuma göre sirasıyla \% $35,27,38$ ve 4'lük artışlar belirlediğini bildirmektedir.

\subsection{C vitamini}

Çizelge 5'ten de görüleceği gibi C vitamini içeriği üzerine tür ve ışılanma süresi uygulamalarının ana etkileri ve interaksiyon önemli bulunmuştur $(\mathrm{P}<0.01)$. Işıkta çimlendirilen tohum filizleri, karanlıkta çimlendirilenlere göre daha yüksek C vitaminine sahip olmuştur. C vitamini kapsamı bakımından en yüksek değer ortalama $72.26 \mathrm{mg} 100$ $\mathrm{g}^{-1}$ ile brokoli filizlerinden elde edilmiş, bunu yine brokolinin yer aldığ 1 lahanagiller karışımı izlemiş (64.01 mg $100 \mathrm{~g}^{-1}$ ) ve en düşük $\mathrm{C}$ vitamini miktarı İran üçgülünde (10.45 mg $100 \mathrm{~g}^{-1}$ ) saptanmıştır. Tür ve karışımları ile ışık uygulamaları arasındaki

Çizelge 4- Tohum karışımları ve ışıklanmanın filizlerin toplam şeker içeriği üzerine etkileri (g $\left.100 \mathrm{~g}^{-1}\right)$

Table 4-Effect of light and seed mixture on total sugar content $\left(\mathrm{g} 100 \mathrm{~g}^{-1}\right)$ of sprouts

\begin{tabular}{|c|c|c|c|c|c|c|c|c|c|c|}
\hline \multirow{2}{*}{ Işık koşulları } & \multicolumn{10}{|c|}{ Toplam şeker $\left(g^{100} \mathrm{~g}^{-1}\right)$} \\
\hline & $I$ & $I I$ & III & $I V$ & V & $V I$ & VII & VIII & $I X$ & Ortalama \\
\hline Işık & $2.15 \mathrm{~h}$ & $3.88 \mathrm{a}$ & $2.59 \mathrm{e}$ & $1.21 \mathrm{~d}$ & $2.99 \mathrm{c}$ & $1.82 \mathrm{~m}$ & $2.35 \mathrm{~g}$ & $2.73 \mathrm{~d}$ & $2.17 \mathrm{~h}$ & $2.43 \mathrm{a}$ \\
\hline Işık+Karanlık & $1.95 \mathrm{kl}$ & $3.43 \mathrm{~b}$ & $2.48 \mathrm{f}$ & $1.09 \mathrm{p}$ & $2.67 \mathrm{de}$ & $1.69 \mathrm{n}$ & $2.07 \mathrm{ij}$ & $2.60 \mathrm{e}$ & $2.02 \mathrm{jk}$ & $2.23 \mathrm{~b}$ \\
\hline Karanlık & $1.87 \mathrm{~lm}$ & $3.52 \mathrm{~b}$ & $2.42 \mathrm{fg}$ & $1.00 \mathrm{p}$ & $2.67 \mathrm{de}$ & $1.62 \mathrm{n}$ & $1.88 \mathrm{~lm}$ & $2.41 \mathrm{fg}$ & $1.98 \mathrm{jk}$ & $2.15 \mathrm{c}$ \\
\hline Ortalama & $1.99 \mathrm{f}$ & $3.62 \mathrm{a}$ & $2.50 \mathrm{~d}$ & $1.10 \mathrm{~h}$ & $2.78 \mathrm{~b}$ & $1.71 \mathrm{~g}$ & $2.10 \mathrm{e}$ & $2.58 \mathrm{c}$ & $2.06 \mathrm{e}$ & \\
\hline
\end{tabular}


etkileşime bakıldığında, en fazla $\mathrm{C}$ vitamini 1 şık koşullarında çimlendirilen brokolide elde edilmiş (78.77 mg $100 \mathrm{~g}^{-1}$ ), bunu sirasiyla brokolinin 1şık+karanlık uygulaması (74.73 mg $\left.100 \mathrm{~g}^{-1}\right)$, brokoli ve Brüksel lahanası karışımının ışık (69.30

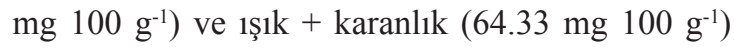
uygulamaları izlemiştir. En düşük $\mathrm{C}$ vitamini

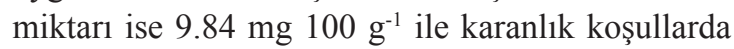
çimlendirilen İran üçgülünde tespit edilmiştir. Tohum filizinin $\mathrm{C}$ vitamini içeriği, ürünün besin ve satış değerini etkileyen ana faktörlerden biridir (Lee et al 2005). Aydınlık ortamda çimlendirilen tohumlarda askorbik asit biyosentezi oldukça yüksek seviyede gerçekleşmektedir (Plaza et al 2003). Çalışmamızda buna paralel olarak, ışık koşullarında çimlenmiş tohum filizlerinde 1şık+karanlık ve karanlık uygulamalarına göre daha yüksek C vitamini tespit edilmiş (Çizelge 5) ve 1şıkta çimlendirme karanlıkta çimlendirmeye göre ortalama \% $20.15^{\prime}$ 'lik artış sağlamıştır. Xu et al (2005) benzer şekilde soyada farklı 6 1şık kalitesi ile kontrol (karanlık) arasında C vitamini içeriği bakımından \% 77'ye varan farklılıklarının olduğunu bildirmektedir. Soya filizlerinde C vitamini 4.76 ile $22.04 \mathrm{mg}$ arasında değişim göstermektedir (No et al 2003). Çalışmamızda, filizlerde $C$ vitamini içeriği açısından tohuma göre \% 229.9 (Brüksel lahanası) ile \% 870.8 (İran üçgülü) arasında artışlar meydana gelmiştir. Benzer şekilde Krug (1991), çimlendirme ile $\mathrm{C}$ vitamini içeriğinin 3-35 kat artabileceğini ifade etmektedir. Plaza et al (2003) de C vitamini miktarının çimlendirilen buğdayda 1.5 , soyada 3 , yoncada 10 kat arttığını tespit etmiştir. Çalışmamızda türler içinde brokoli en yüksek C vitaminini (72.26 mg $\left.100 \mathrm{~g}^{-1}\right)$ vermiş, bunu lahanagil karışımı (64.01 mg $100 \mathrm{~g}^{-1}$ ) ile Brüksel lahanası (57.71 mg 100 $\mathrm{g}^{-1}$ ) takip etmiştir (Çizelge 5). Yine çalışmamızda, çimlendirme beş gün süreyle devam etmiştir. Oysa, Orhun \& Arın (2008) turpta çimlendirme ortamı ve süresine bağlı olarak 62.1 ile $162.7 \mathrm{mg}$ aras1 $\mathrm{C}$ vitamini olduğunu ve çimlendirme süresinin 2 günden 5 güne çıkarılması ile $\mathrm{C}$ vitamininde azalış meydana geldiğine dikkat çekmiştir. Sonuçlarımız, insan sağlığı açısından, özellikle lahanagillerin filizlerinin ve onların karışımlarının, farklı yaş ve cinsiyet gruplarına göre 45-90 mg olarak önerilen günlük C vitamini gereksinimini (IOM 2008; ANVY 2008), $100 \mathrm{~g}$ yenmesi halinde tek başına karş1layabilecek nitelikte olduğunu göstermektedir.

\subsection{Kalsiyum}

Tohum filizlerinin Ca içeriği üzerine, uygulamaların ana etkileri ve interaksiyonun önemli olduğu saptanmıştır $\quad(\mathrm{P}<0.01) . \quad$ Işıklanma süresi bakımından, 1şık ve 1 şı + karanlık uygulamaları arasındaki farklılık önemli çıkmış ancak farklılık çok küçük olmuştur (Çizelge 6). Türler açısından incelendiğinde genel olarak baklagil filizlerinin lahanagil filizlerine göre daha fazla $\mathrm{Ca}$ içerdiği görülmüştür. $\mathrm{Bu}$ açıdan soya fasulyesi filizleri

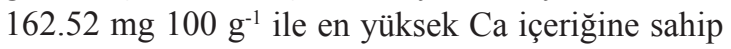
iken Brüksel lahanası $36.04 \mathrm{mg} 100 \mathrm{~g}^{-1}$ ile en düşük değeri vermiştir. Öte yandan, uygulamalar birlikte değerlendirildiğinde en yüksek Ca içeriği (163.10 mg $100 \mathrm{~g}^{-1}$ ) 1ş1kta çimlendirilen soya fasulyesi filizlerinde elde edilmiş, Brüksel lahanası ise tüm

Çizelge 5- Tohum karışımları ve ışıklanmanın filizlerin $C$ vitamini içeriği üzerine etkileri (mg $\left.100 \mathbf{~ g}^{-1}\right)$

Table 5-Effect of light and seed mixture on vitamin C content $\left(\mathrm{mg} 100 \mathrm{~g}^{-1}\right)$ of sprouts

\begin{tabular}{|c|c|c|c|c|c|c|c|c|c|c|}
\hline \multirow{2}{*}{ Işık koşulları } & \multicolumn{10}{|c|}{$C$ vitamini $\left(\mathrm{mg} 100 \mathrm{~g}^{-1}\right)$} \\
\hline & $I$ & II & $I I I$ & $I V$ & $V$ & $V I$ & $V I I$ & VIII & $I X$ & Ortalama \\
\hline Işı1k & $78.77 \mathrm{a}$ & $61.93 \mathrm{~d}$ & $14.87 \mathrm{~m}$ & $11.37 \mathrm{np}$ & $69.30 \mathrm{c}$ & $13.63 \mathrm{mn}$ & $43.63 \mathrm{~h}$ & $56.83 \mathrm{ef}$ & $27.90 \mathrm{j}$ & $42.03 \mathrm{a}$ \\
\hline Işık + Karanlık & $74.73 b$ & $57.43 \mathrm{e}$ & $13.07 \mathrm{mo}$ & $10.13 \mathrm{p}$ & $64.33 \mathrm{~d}$ & $11.77 \mathrm{np}$ & $43.23 \mathrm{~h}$ & $54.17 \mathrm{fg}$ & $24.30 \mathrm{k}$ & $39.24 b$ \\
\hline Karanlık & $63.27 \mathrm{~d}$ & $53.77 \mathrm{~g}$ & $11.30 \mathrm{np}$ & $9.84 \mathrm{p}$ & $58.40 \mathrm{e}$ & 10.77 op & 34.031 & $52.13 \mathrm{~g}$ & 21.401 & $34.98 \mathrm{c}$ \\
\hline Ortalama & $72.26 \mathrm{a}$ & $57.71 \mathrm{c}$ & $13.08 \mathrm{~g}$ & $10.45 \mathrm{~h}$ & $64.01 \mathrm{~b}$ & $12.03 \mathrm{~g}$ & $40.30 \mathrm{e}$ & $54.38 \mathrm{~d}$ & $24.53 \mathrm{f}$ & \\
\hline
\end{tabular}


1şıklanma koşullarında en düşük $\mathrm{Ca}$ içermiştir. Plaza et al (2003) tohumların çimlendirilmesi ile $\mathrm{Ca}$ içeriğinde kuru ağırlık bazında 3 kat artış olduğunu, Zielinski et al (2005) de kolza, turp, hardal gibi lahanagillerde tohuma göre Ca miktarının \% 12 oranında arttığını belirtmiştir. Oysa bu çalışmada, farklı 1şık koşulları filizlerin $\mathrm{Ca}$ içeriğinde belirleyici olmamış ve çimlendirme sonrasında tohumların çimlendirme öncesindeki $\mathrm{Ca}$ içeriğine paralel değerler elde edilmiştir (Çizelge 2,6). Bu sonuçlar, diğer çalışmalarda da belirtildiği gibi tür, çeşit, çimlendirme ortamı, süresi, yıkama suyu gibi faktörlerden kaynaklanabilmektedir (Billings, 2014).

\subsection{Fosfor}

Türler ve karışımları arasında görülen farklılıklar istatistiki olarak önemli bulunmuştur $(\mathrm{P}<0.01$, Çizelge 7). En yüksek P içeriğini $66.22 \mathrm{mg} 100$ $\mathrm{g}^{-1}$ ile soya fasulyesi vermiş, bunu $65.42 \mathrm{mg} 100$ $\mathrm{g}^{-1}$ ile brokoli izlemiştir. Bu sonuçlar, brokolide 66 mg P bulunduğunu ifade eden Lorenz ve Maynard (1988)'ın ve soya filizinin $58 \mathrm{mg} \mathrm{P}$ içerdiğini bildiren Liebster (1991)'ın sonuçlarına paralellik göstermektedir. Tohum filizlerinin $\mathrm{P}$ içerikleri de tohumların $\mathrm{P}$ içeriğine yakın olmuş, soya ve brokolinin P içerikleri diğerlerine göre daha yüksek bulunmuştur.

\subsection{Potasyum}

Tohum filizlerinin $\mathrm{K}$ içeriği üzerine tohum karışımları ve 1şıklanma süresi istatistikî önemde etkili olmuştur (Filiz için $\mathrm{P}<0.05$, Işı1k için $\mathrm{P}<0.01$, Çizelge 8). En yükssek K içeriği soya fasulyesinde (439.30 mg $100 \mathrm{~g}^{-1}$ ) belirlenmiş ve bunu 320.96 mg $100 \mathrm{~g}^{-1}$ ile brokoli izlemiştir. Benzer şekilde Lorenz ve Maynard (1988), brokolide $325 \mathrm{mg}$, Liebster (1991) ise soyada $418 \mathrm{mg} \mathrm{K}$ bulunduğunu ifade etmiştir. En düşük $\mathrm{K}$ içeriğini ise $87.12 \mathrm{mg}$ $100 \mathrm{~g}^{-1}$ ile İran üçgülü vermiştir. Karışımların ise, karışımı oluşturan her bir türün ayrı ayrı içerdiği $\mathrm{K}$ miktarı ile orantılı olarak $\mathrm{K}$ ihtiva

Çizelge 6- Tohum karışımları ve ışıklanmanın filizlerin kalsiyum içeriği üzerine etkileri (mg $\left.100 \mathrm{~g}^{-1}\right)$

Table 6-Effect of light and seed mixture on calcium content ( $\left.\mathrm{mg} 100 \mathrm{~g}^{-1}\right)$ of sprouts

\begin{tabular}{|c|c|c|c|c|c|c|c|c|c|c|}
\hline \multirow{2}{*}{ Işılk koşulları } & \multicolumn{10}{|c|}{ Kalsiyum (mg $\left.100 \mathrm{~g}^{-1}\right)$} \\
\hline & $I$ & II & $I I I$ & $I V$ & $V$ & $V I$ & VII & VIII & $I X$ & Ortalama \\
\hline Iş1k & 47.871 & $36.13 \mathrm{o}$ & $163.10 \mathrm{a}$ & $112.97 \mathrm{f}$ & $41.93 n$ & $137.57 \mathrm{~cd}$ & 92.271 & $64.93 \mathrm{j}$ & $133.33 \mathrm{ef}$ & $90.01 \mathrm{a}$ \\
\hline Işık+Karanlık & $47.43 \mathrm{~lm}$ & $35.97 \mathrm{o}$ & $162.00 \mathrm{~b}$ & $112.17 \mathrm{~g}$ & $41.80 \mathrm{n}$ & $136.93 \mathrm{~d}$ & 92.531 & $64.33 \mathrm{jk}$ & 113.77 e & 89.66 b \\
\hline Karanlık & $47.03 \mathrm{~m}$ & $36.03 \mathrm{o}$ & $162.47 \mathrm{ab}$ & 113.13 ef & $42.00 \mathrm{n}$ & $137.13 \mathrm{c}$ & $93.37 \mathrm{~h}$ & $64.23 \mathrm{k}$ & $113.40 \mathrm{ef}$ & $89.93 \mathrm{ab}$ \\
\hline Ortalama & $47.44 \mathrm{~g}$ & 36.041 & $162.52 \mathrm{a}$ & $112.76 \mathrm{~d}$ & $41.91 \mathrm{~h}$ & $137.41 \mathrm{~b}$ & $92.72 \mathrm{e}$ & $64.50 \mathrm{f}$ & $113.50 \mathrm{c}$ & \\
\hline
\end{tabular}

Çizelge 7- Tohum karışımları ve ışıklanmanın filizlerin fosfor içeriği üzerine etkileri (mg $\left.100 \mathrm{~g}^{-1}\right)$

Table 7- Effect of light and seed mixture on phosphorus content ( $\left.\mathrm{mg} 100 \mathrm{~g}^{-1}\right)$ of sprouts

\begin{tabular}{lcccccccccc}
\hline \multirow{2}{*}{ Işılk koşulları } & \multicolumn{10}{c}{ Fosfor $\left(\mathrm{mg} 100 \mathrm{~g}^{-1}\right)$} \\
\cline { 2 - 11 } & $I$ & $I I$ & $I I I$ & $I V$ & $V$ & $V I$ & $V I I$ & VIII & IX & Ortalama \\
\hline Işık & 65.83 & 55.83 & 67.27 & 47.33 & 60.87 & 43.83 & 53.70 & 56.90 & 48.20 & $55.53 \mathrm{~ns}$ \\
Işı1k+Karanlık & 65.20 & 55.70 & 65.87 & 47.10 & 60.53 & 43.87 & 54.20 & 57.03 & 48.10 & $55.30 \mathrm{~ns}$ \\
Karanlık & 65.23 & 55.67 & 65.53 & 47.33 & 60.60 & 43.90 & 54.00 & 56.80 & 47.37 & $55.16 \mathrm{~ns}$ \\
\hline Ortalama & $65.42 \mathrm{~b}$ & $55.73 \mathrm{e}$ & $66.22 \mathrm{a}$ & $47.26 \mathrm{~g}$ & $60.67 \mathrm{c}$ & $43.87 \mathrm{~h}$ & $53.97 \mathrm{f}$ & $56.91 \mathrm{~d}$ & $47.89 \mathrm{~g}$ & \\
\hline
\end{tabular}

Tohum filizi karışımları, $\mathrm{LSD}_{0.01}=0.696$; ns, önemli değil 
Çizelge 8- Tohum karışımları ve ışıklanmanın filizlerin potasyum içeriği üzerine etkileri (mg $\left.100 \mathrm{~g}^{-1}\right)$

Table 8-Effect of light and seed mixture on potassium content $\left(\mathrm{mg} 100 \mathrm{~g}^{-1}\right)$ of sprouts

\begin{tabular}{|c|c|c|c|c|c|c|c|c|c|c|}
\hline \multirow{2}{*}{ Işık koşulları } & \multicolumn{10}{|c|}{ Potasyum (mg $\left.100 \mathrm{~g}^{-1}\right)$} \\
\hline & $I$ & II & III & $I V$ & V & $V I$ & $V I I$ & VIII & $I X$ & Ortalama \\
\hline Işık & 322.47 & 317.00 & 439.27 & 87.20 & 319.90 & 259.90 & 287.77 & 303.83 & 274.63 & $290.22 \mathrm{a}$ \\
\hline Işık +Karanlık & 320.43 & 317.03 & 438.73 & 87.17 & 318.97 & 257.83 & 287.07 & 305.27 & 273.87 & $289.60 \mathrm{~b}$ \\
\hline Karanlık & 319.97 & 283.57 & 439.90 & 87.00 & 319.53 & 257.23 & 287.13 & 304.53 & 274.53 & $285.93 \mathrm{c}$ \\
\hline Ortalama & $320.96 \mathrm{~b}$ & $305.87 \mathrm{~d}$ & $439.30 \mathrm{a}$ & 87.121 & $319.47 \mathrm{c}$ & $258.32 \mathrm{~h}$ & $287.32 \mathrm{f}$ & $304.54 \mathrm{e}$ & $274.34 \mathrm{~g}$ & \\
\hline
\end{tabular}

ettiği görülmüştür. Ayrıca, filizlerin $\mathrm{K}$ içeriği ile tohumlarının $\mathrm{K}$ içeriği yaklaşık aynı seviyede olmuştur (Çizelge 2). Örneğin, $439.8 \mathrm{mg} 100 \mathrm{~g}^{-1}$ ile tohumlar arasında en yüksek K miktarının görüldüğ̈̈ soyanın, filizlerinin $439.30 \mathrm{mg} 100$ $\mathrm{g}^{-1}$ değerini verdiği, tohumu en az $\mathrm{K}$ içeren İran üçgülünün $\left(86.8 \mathrm{mg} 100 \mathrm{~g}^{-1}\right)$ de filizler arasında en düşük (87.12 mg $\left.100 \mathrm{~g}^{-1}\right) \mathrm{K}$ değerini gösterdiği dikkati çekmektedir.

\section{Sonuçlar}

Lahanagil ve baklagil familyalarındaki 4 tür ve tür karışımlarına ait tohumların tam gün 1şıklanma koşullarında çimlendirilmesi, fotosenteze bağlı olarak, karanlığa göre filizlerin daha yüksek protein, şeker ve $\mathrm{C}$ vitamini içeriğine sahip olmasını sağlamıştır. Bununla birlikte her ne kadar duyusal analizler yapılmamış olsa da 1 şı koşullarında üretilen filizlerde doku sertleşmesi gözlenmiştir. Tohumların çimlendirmesi öncesi ve sonrası karşılaştırıldığında genel olarak protein miktarı değişmemiş, şeker bir miktar, $\mathrm{C}$ vitamini ise önemli oranda artmış, $\mathrm{Ca}, \mathrm{P}$ ve $\mathrm{K}$ içeriğinde ise tohuma göre farklılık görülmemiştir. Sonuçlar, tohumların özelliklerini karışımlara bağlı olmaksızın çimlendirme sonrası da korumaları nedeniyle, filizlerin ayrı ayrı üretilip tüketim aşamasında karıştırılabileceğini göstermektedir. Fonksiyonel gida kapsamında lahanagiller ve özellikle de brokoli ile ilgili çalışmalara devam edilmesinde yarar vardır.

\section{Teşekkür}

$\mathrm{Bu}$ çalışma TÜBİTAK tarafından desteklenmiş olup $107 \mathrm{O} 266$ nolu projenin bir bölümüdür. Katkılarından dolayı TÜBİTAK'a teşekkür ederiz.

\section{Kaynaklar}

Açıkgöz N, Akbaş M E, Moghaddam A \& Özcan K (1994). PC'ler için veri tabanı esaslı türkçe istatistik paketi: TARIST, Türkiye I. Tarla Kongresi, 24-28 Nisan, İzmir, s. 264-267

ANYV (2008). Recommended dietary allowance of vitamins and other nutrients. www.anyvitamins.com/ rda.htm (Access Date: 22 January 2014)

AOAC (1999). Official Methods of Analysis. Association of Official Analytical Chemists, Washington, DC., pp. 1141

Arın L (1997). Sebze olarak çimlendirilmiş tohum nedir? Hasad 144-145: 41-43

Billings T E (2014). Sprouting: A Brief Overview. http:// www.living-foods.com/articles/sprouting.html (Access Date: 03 January 2014)

Fahey J W (2005). Role of glucoraphanin/sulfurophane from broccoli and broccoli sprouts in protection against cancer and other oxidative and degenerative diseases. 2005 IFT Annual Meeting, July 15-20, New Orleans, Louisiana

Fahey J W, Zhang Y \& Talalay P (1997). Broccoli sprouts: An exceptionally rich source of inducers of enzymes that protect against chemical carcinogens. Proceedings of the National Academy of Sciences of USA 94: 10367-10372 
Farnham M W, Stephenson K K \& Fahey J W (2005). Glucoraphanin level in broccoli seed is largely determined by genotype. HortScience 40(1): 50-53

Faulkner K, Mithen R \& Williamson G (1998). Selective increase of the potential anticarcinogen 4-methylsulphinylbutyl glucosinolate in broccoli. Carcinogenesis 19(4): 605-609

IOM (2008). Dietary reference intakes. www.iom.edu/ Object.File/Master/21/372/0.pdf (Access Date: 22 January 2008)

Kim E H, Kim S H, Chung J I, Chi H Y, Kim J A \& Chung I M (2006). Analysis of phenolic compounds and isoflovones in soybean seeds (Glycine max (L) Merill) and sprouts grown under different conditions. European Food Research and Technology 222: 201208

Krug H (1991). Gemüseproduktion, 2. Auflage. Verlag Paul Parey, Berlin und Hamburg

Kurtzweil P (1999). Questions keep sprouting about sprouts. FDA Consumer, January- February, pp. 18-22

Lee Y S, Kim Y H \& Kim S B (2005). Changes in the respiration, growth, and vitamin $\mathrm{C}$ content of soybean sprouts in response to chitosan of different molecular weights. HortScience 40(5): 1333-1335

Liebster G (1991). Warenkunde, Gemüse, Band 2. Morion Verlagproduktion $\mathrm{GmbH}$, Düsseldorf

Lorenz O A \& Maynard D N (1988). Knott's Handbook for Vegetable Growers (Third Edition). WileyInterscience Publication, New York

No H K, Lee K S, Kim I D, Park M J, Kim S D \& Meyers S D (2003). Chitosan treatment affects yield, ascorbic acid content, and hardness of soybean sprouts. Journal of Food Science 68(2): 680-685

Orhun G E \& Arın L (2008). Determining the best sprouting conditions for germination of radish
(Raphanus sativus) seeds consumed as vegetables. Journal of Food, Agriculture \& Environment 6(1): 123-127

Pearson D (1970). Analysis. Determination of L. Ascorbic Acid. International Federation of Fruit-Juice Producers, No: 17

PHY (2014). Phytochemicals. www.phytochemicals.info/ plants/broccoli.php (Access Date: 03 January 2014)

Plaza L, Ancos B \& Cano M P (2003). Nutritional and health-related compounds in sprouts and seeds of soybean (Glycine max), wheat (Triticum aestivum L.) and alfalfa (Medicago sativa) treated by a new drying method. European Food Research and Technology 216: $138-144$

Soylemez G, Brashears M M, Smith D A \& Cuppett S L (2001). Microbial quality of alfalfa seeds and sprouts after a chlorine treatment and packaging modifications. Journal of Food Science 66(1): 153157

TOKB (1988). Gıda Maddeleri Muayene ve Analiz Metodları. Tarım, Orman ve Köyişleri Bakanlığı, Koruma ve Kontrol Müdürlüğü, Bursa

Weiss A \& Hammes W P (2005). Efficacy of heat treatment in the reduction of salmonellae and Escherichia coli O157: $\mathrm{H}^{-}$on alfalfa, mung bean and radish seeds used for sprout production. European Food Research and Technology 221: 187-191

Xu M J, Dong J F \& Zhu M Y (2005). Effects of germination conditions on ascorbic acid level and yield of soybean sprouts. Journal of the Science of Food and Agriculture 85(6): 943-947

Zielinski H, Frias J, Piskula M K, Kozlowska H \& VidalValverde C (2005). Vitamin $B_{1}$ and $B_{2}$, dietary fiber and minerals content of Cruciferae sprouts. Journal of the Science of Food and Agriculture 221: 78-83 